\title{
Length-weight relationships and biomass of the main microcrustacean species of two large tropical reservoirs in Brazil
}

\author{
Brito, SL. ${ }^{a}$, Maia-Barbosa, PM. ${ }^{b}$ and Pinto-Coelho, $R M .^{b}$ \\ ${ }^{a}$ Fundação Centro Internacional de Educação, Capacitação e Pesquisa Aplicada em Águas - UNESCO-HidroEX, \\ Av. Mário Palmério, 1000, CEP 38200-000, Frutal, MG, Brazil \\ ${ }^{b}$ Universidade Federal de Minas Gerais, Av. Antônio Carlos, 6627, CEP 30161-970, Belo Horizonte, MG, Brazil \\ *e-mail: brito_sofia@yahoo.com
}

Received July 31, 2012 - Accepted September 28, 2012 - Distributed August 31, 2013

(With 2 figures)

\begin{abstract}
Length-weight equations were determined for the main microcrustacean species of Três Marias and Furnas reservoirs (state of Minas Gerais, Brazil), and evaluated the fluctuations of their biomass. We examined the following species: Thermocyclops minutus, Bosminopsis deitersi, Bosmina hagmanni, Ceriodaphnia cornuta, and Moina minuta (Três Marias Reservoir), and Notodiaptomus henseni, Daphnia ambigua, Ceriodaphnia silvestrii, Diaphanosoma spinulosum, D. fluviatile, and Bosmina freyi (Furnas Reservoir). Dry weight was obtained in a microbalance for each size class (Cladocera) or developmental stage (Copepoda). Microcrustacean mean biomass varied from $5.76 \mathrm{mg}$ DW. $\mathrm{m}^{-3}$ and $20.36 \mathrm{mg} \mathrm{DW} . \mathrm{m}^{-3}$ (Furnas Reservoir) and from $3.75 \mathrm{mg} \mathrm{DW} . \mathrm{m}^{-3}$ and $18.14 \mathrm{mg}$ DW.m $\mathrm{m}^{-3}$ (Três Marias Reservoir). Significant differences $(\mathrm{p}<0.000)$ between seasons were registered with higher biomass during the rainy seasons. Thermocyclops minutus was the most important species in Três Marias, whereas in Furnas, N. henseni contributed in equal proportion. In Furnas, the higher cladoceran biomass was explained by the contribution of larger-sized species, such as D. ambigua, C. silvestrii, D. spinulosum, and D. fluviatile. Even though both reservoirs are considered oligotrophic, there were significant differences in the estimated microcrustacean biomass, which reinforces the importance of this parameter for the description of the real contribution of each species in the community.
\end{abstract}

Keywords: length-weight relationships, body size, dry weight, microcrustacean biomass, tropical reservoirs.

\section{Regressões peso-comprimento e biomassa das principais espécies de microcrustáceos de dois grandes reservatórios tropicais no Brasil}

\section{Resumo}

Equações peso-comprimento foram determinadas para as principais espécies de microcrustáceos dos reservatórios de Três Marias e Furnas (Minas Gerais, Brasil), assim como a flutuação de sua biomassa. Foram consideradas as espécies mais abundantes: Thermocyclops minutus, Bosminopsis deitersi, Bosmina hagmanni, Ceriodaphnia cornuta, e Moina minuta (Reservatório de Três Marias) e Notodiaptomus henseni, Daphnia ambigua, Ceriodaphnia silvestrii, Diaphanosoma spinulosum, D. fluviatile e Bosmina freyi (Reservatório de Furnas). O peso seco foi obtido em microbalança para cada classe de tamanho no caso dos Cladocera ou para cada estágio do desenvolvimento no caso dos Copepoda. Valores médios de biomassa dos microcrustáceos variaram de 5,76 mg PS.m ${ }^{-3}$ a 20,36 mg PS.m ${ }^{-3}$ (Reservatório de Furnas) e de 3,75 mg PS.m ${ }^{-3}$ a 18,14 mg PS.m ${ }^{-3}$ (Reservatório de Três Marias), durante os períodos de seca e chuva, respectivamente. Diferenças significativas $(p<0.000)$ foram registradas entre os períodos com maior biomassa durante os períodos de chuva. Thermocyclops minutus foi a espécie mais importante em Três Marias, enquanto em Furnas, $N$. henseni contribuiu em igual quantidade para a biomassa. Em Furnas, a maior biomassa de Cladocera foi observada devido a espécies de maior tamanho corporal como D. ambigua, C. silvestrii, D. spinulosum, e D. fluviatile. Mesmo ambos os reservatórios considerados oligotróficos, há diferenças significativas na biomassa de microcrustáceos, que reforçam a importância deste parâmetro para determinar a real contribuição de cada espécie na comunidade.

Palavras-chave: equações peso-comprimento, tamanho de corpo, peso seco, biomassa de microcrustáceos, reservatórios tropicais. 


\section{Introduction}

The majority of studies on the zooplankton community in Brazilian aquatic ecosystems involve only the taxonomic list or the numerical densities of these organisms. However, because of the wide range in body size (from $\mu \mathrm{m}$ to $\mathrm{cm}$ ), this community is better characterized by the biomass (McCauley, 1984; Rocha et al., 1995; Bozelli and Huszar, 2003). Some taxa that contribute significantly in numbers, such as rotifers and protozoans, have less importance for biomass, whereas the larger-sized copepods and cladocerans may be more important for this parameter (Pace, 1986; Matsumura-Tundisi et al., 1989; Melão et al., 2005; Bonecker et al., 2007). Moreover, because of their larger body size compared to rotifers, microcrustaceans are preferential prey of fish, especially visual predators (Sá Júnior, 1994).

The need for high-precision equipment is one of the main reasons for the relatively few studies on zooplankton biomass, and explains why many studies use lengthweight regressions described in the literature (Esteves and Sendacz, 1988; Bezerra-Neto and Pinto-Coelho, 2002; Pinto-Coelho et al., 2005a; Corgosinho and PintoCoelho, 2006; Panarelli et al., 2010; Santos et al., 2010). Most often, these regressions are generalizations for higher taxonomic levels and are based on species of temperate climates. Moreover, species-specific effects (lifecycle duration, assimilation capacity, and nutritional state), environmental variables (temperature, pollution, climate and geographical factors, nutrients, food quantity and quality, predation) and methodological particularities (preservation or not in formalin, time of preservation, measurement criteria) may influence the determination of the length-weight regression of each species (Bottrell et al., 1976; McCauley, 1984; Blettler and Bonecker, 2006).

Recently, with the development of limnological research in Brazil and wider acquisition of microbalances (an instrument capable of making precise measurements of weight of objects of relatively small mass: of the order of a million parts of a gram), studies on length-weight relationships (Maia-Barbosa and Bozelli, 2005; Santos et al., 2006; Castilho-Noll and Arcifa, 2007) and dry weight and biomass (Melão and Rocha, 2004 and 2006; Sendacz et al., 2006; Magalhães et al., 2006; Blettler and Bonecker, 2007; Bonecker et al., 2007; González et al., 2008; Rosa, 2008) have increased.

Studies that consider biomass values are important because they allow comparison of different environments, providing a common unit to evaluate zooplankton groups. Generally, eutrophic environments support higher biomass of smaller individuals than more oligotrophic ones (Pace, 1986; Esteves and Sendacz, 1988). Biomass studies are also important to determine secondary production, another parameter that is relatively seldom evaluated in Brazil.

Aiming to increase fish production in Três Marias and Furnas reservoirs, the project "Technical-Scientific Study to Delimit Aquaculture Areas in the Lakes of
Furnas and Três Marias Reservoirs - MG, Brazil" (SEAP/SECTES/FUNDEP-UFMG), of which this study is a part, was proposed to select areas with oligotrophic waters within these reservoirs to install cage systems for tilapia farming. In this project, abiotic and biotic variables were measured to estimate the support capacity of these areas, with the objective of minimizing the impact on water quality. The knowledge generated about the zooplankton will help, in the future, to use these organisms as a food source for fish as well as possible bioindicators for monitoring water quality, mitigating the impacts of fish production on aquatic communities.

In this context, the aim of this study was to determine length-weight relationships of the main microcrustacean species of two tropical reservoirs, Três Marias and Furnas (state of Minas Gerais), as well as to evaluate the biomass fluctuations of these species in two arms of these reservoirs, during the dry and rainy seasons. In this context, we also made a complete comparison with all papers available that provide values of microcrustaceans size, dry weight and biomass in many lakes and reservoirs of Brazil considering their trophic state.

\section{Material and Methods}

\subsection{Study area}

Três Marias $\left(18^{\circ} 12^{\prime} \mathrm{S}\right.$ and $\left.45^{\circ} 15^{\prime} \mathrm{W}\right)$ and Furnas $\left(46^{\circ} 19^{\prime} \mathrm{W}\right.$ and $\left.20^{\circ} 40^{\prime} \mathrm{S}\right)$ are two large reservoirs in the state of Minas Gerais (Brazil). Both were constructed ca. 40 years ago, mainly for power generation, and are also used for recreation, professional and sport fishing, irrigation, and water supply. Três Marias Reservoir is located on the Upper São Francisco River in the central-western part of Minas Gerais. The reservoir was completed in 1960, and silting is the main impact that compromises its power generation and water quality, followed by the replacement of the vegetation along the shore by Eucalyptus plantations and large cattle ranches (Sampaio and López, 2003). Furnas Reservoir is located in the Grande River basin in southern Minas Gerais; its north arm is represented by the Grande River, and the south arm by the Sapucaí River. This reservoir was completed in 1962, and the main impacts are monoculture crops and cattle ranching, sewage discharge, solid residues, and loading of agricultural chemicals (Nogueira et al., 2008). Some morphometric characteristics of the two reservoirs are presented in Table 1.

In each reservoir, we selected two arms with different surrounding land uses (see Figure 1). In Três Marias Reservoir, we selected the Barrão arm $\left(Z_{\max }=21.8 \mathrm{~m}\right.$, with preserved Cerrado, the Brazilian savanna) and Extrema $\operatorname{arm}\left(\mathrm{Z}_{\max }=20.9 \mathrm{~m}\right.$, with Eucalyptus monoculture), located between Morada Nova de Minas and Três Marias municipalities. In Furnas Reservoir, we selected the Varjão $\operatorname{arm}\left(Z_{\max }=17.5 \mathrm{~m}\right.$, with headwaters in Paredão Municipal Park and coffee monoculture in the surroundings) and the Mendonça arm $\left(Z_{\max }=25.5 \mathrm{~m}\right.$, with cattle ranching on native grasslands), located between Guapé and 
Table 1 - Morphometric characteristics of Três Marias and Furnas reservoirs, Minas Gerais. Source: CEMIG (2009) and FURNAS (2009).

\begin{tabular}{lcc}
\hline Reservoir & Três Marias & Furnas \\
\hline Flooded area & $1100 \mathrm{~km}^{2}$ & $1440 \mathrm{~km}^{2}$ \\
Volume & $15.27 \times 10^{9} \mathrm{~m}^{3}$ & $17.21 \times 10^{9} \mathrm{~m}^{3}$ \\
Average outflow & $700 \mathrm{~m} 3 . \mathrm{s}^{-1}$ & $800 \mathrm{~m} 3 . \mathrm{s}^{-1}$ \\
Retention time & 120 days & 160 days \\
Maximum depth & $75 \mathrm{~m}$ & $90 \mathrm{~m}$ \\
Mean depth & $12 \mathrm{~m}$ & $13 \mathrm{~m}$ \\
Installed capacity & $396 \mathrm{MW}$ & $1126 \mathrm{MW}$ \\
\hline
\end{tabular}

Capitólio municipalities. These arms were selected in order to reflect the different land uses around the reservoirs.

\subsection{Procedures}

Samples were collected every two days, during four weeks, in two dry seasons (July/August 2006 and July/August 2007) and two rainy seasons (January/March 2007 and January/March 2008), considered the most representative of the variations in temperature and precipitation. In the project "Technical-Scientific Study to Delimit Aquaculture Areas in the Lakes of Furnas and Três Marias Reservoirs - Minas Gerais, Brazil", the cages will be located within the arms to avoid the effect of reservoir management. Thus, samples were collected at the midpoint of each arm, in the limnetic region, far from the main channel of São Francisco and Grande Rivers.

For the qualitative and quantitative zooplankton samples, vertical hauls were made with a plankton net of
$68 \mu \mathrm{m}$ mesh size. Because of the presence of drowned original vegetation ("paliteiros") at the sampling stations, hauls were made in the euphotic zone as determined by Secchi disk. Organisms were narcotized with gasified water, stained with Rose Bengal, and preserved with 4\% buffered formalin. Subsamples of $1.0 \mathrm{~mL}$ were counted in an Olympus (CBA) optical microscope, in a Sedgewick-Rafter chamber. The data are presented as organisms per $\mathrm{m}^{3}$. During the counts, nauplii, copepodids, and adults of each species of Copepoda were enumerated. The literature used to identify species could be find in Brito et al. (2011).

For this work, we considered the most abundant microcrustacean species (those that comprised at least $5 \%$ of the zooplankton community during the sampling seasons): Thermocyclops minutus Lowndes, Bominopsis deitersi Richard, Bosmina hagmanni Stingelin, Ceriodaphnia cornuta Sars, and Moina minuta Hansen in Três Marias Reservoir; and in Furnas Reservoir, in addition to these species, we also considered Notodiaptomus henseni Dahl, Daphnia ambigua Scourfield, Ceriodaphnia silvestrii Daday, Diaphanosoma spinulosum Herbst, D. fluviatile Hansen, and Bosmina freyi De Melo and Hebert. Detailed description of zooplankton community of Três Marias and Furnas reservoirs can be found in Brito et al. (2011).

To determine the length-weight relationships, we used specimens from the dry season of 2006, when 30 individuals from each size class (determined for Cladocera) or stages of development (Copepoda) (Bird and Praire, 1985) were measured with an ocular micrometer. Nauplii of T. minutus were the exception once 200 individuals were measured and weighed due to smaller weight. For Copepoda, the measurements were made from the cephalothorax to abdomen, excluding the furca

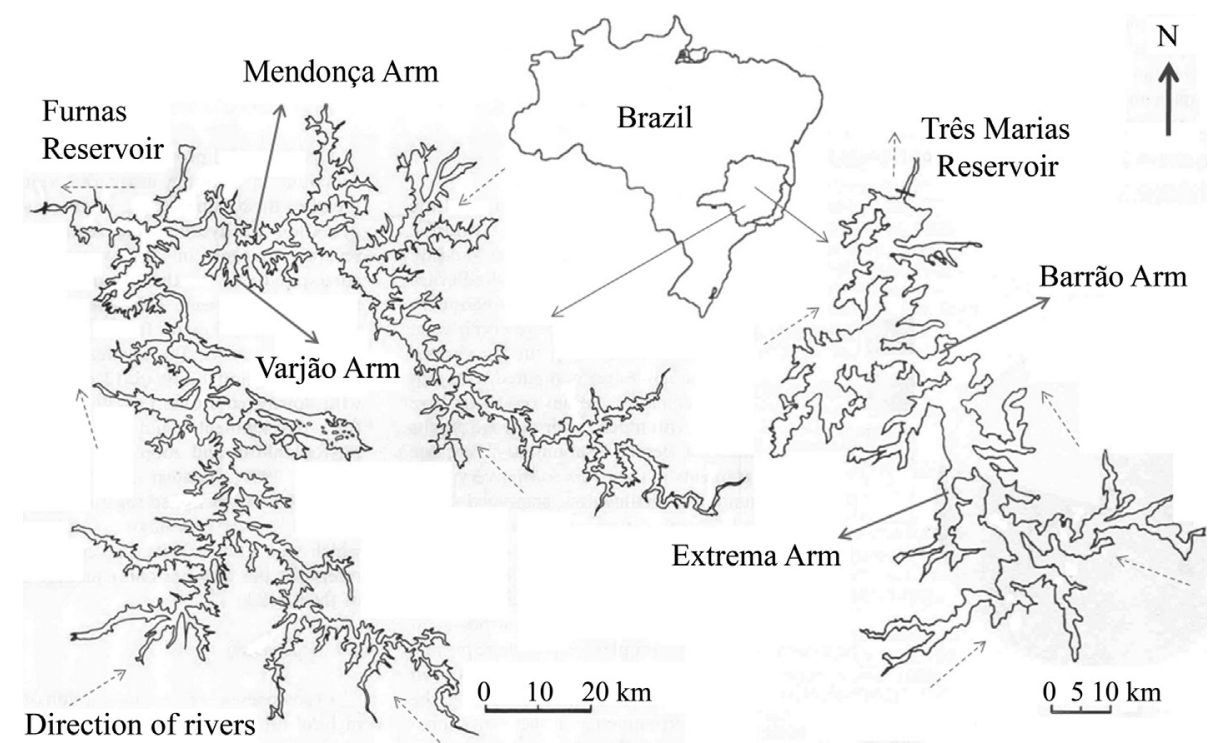

Figure 1 - Três Marias (right, 1:10.000) and Furnas (left, 1:20.000) reservoirs, Minas Gerais. Full arrows indicate arms studied. Dotted arrows indicate direction of river flow. Modified from López and Sampaio, 2003 and Tundisi et al., 1993. 
or caudal ramus; for Cladocera, measurements were made from the head to the base of the carapace, excluding the spine. For Daphnia ambigua, the measurements were made from the base of the helmet to the base of the carapace, excluding the spine. In this way, we determined the size classes and the percent contribution of neonates, juveniles, and adults of cladoceran species. The specimens were rinsed three times in distilled water, and eggs and embryos were removed from adult females, dried at $60{ }^{\circ} \mathrm{C}$ for $24 \mathrm{~h}$ (Bottrell et al., 1976; McCauley, 1984), and weighed in a Sartorius SE2 microanalytical balance (accuracy of $0.1 \mu \mathrm{g}$ ). The data are presented as dry weight (DW). Although the literature contains reports of weight losses of 10 to $40 \%$ for preserved organisms (Dumont et al., 1975; McCauley, 1984; Blettler and Bonecker, 2006), we made no correction for losses due to preservation.

Mean dry weights for each size class (Cladocera) or stages of development (Copepoda) were used to determine length-weight regression after logarithmic transformation of weight (W in $\mu \mathrm{g} \mathrm{DW}$ ) and length ( $\mathrm{L}$ in $\mathrm{mm}$ ), according to the formula of Bottrell et al. (1976):

$$
\mathrm{LnW}=\mathrm{Lna}+\mathrm{b} \operatorname{LnL}
$$

where $\mathrm{a}=$ estimate of intercept and $\mathrm{b}=$ estimate of slope.

Using length-weight regressions and lengths obtained for other sampling seasons, it was possible to estimate biomass from the product of density (org. $\mathrm{m}^{-3}$ ) and mean dry weight ( $\mu \mathrm{gDW}$ ) (Winberg and Duncan, 1971) for Três Marias and Furnas reservoirs. Biomass data are presented as mg DW. $\mathrm{m}^{-3}$.

Differences in values of length and dry weight were assessed through Student's T test, while differences in biomass values between arms, reservoirs, and seasons (dry and rainy) were tested through two-way Analysis of Variance, followed by a Tukey's post-hoc comparison test (Sampaio, 2002). All statistical analyses and regressions were performed with Statistica 7.0 (StatSoft).

\section{Results}

Considering the density, Copepoda was the dominant group, comprising $50.6 \%$ of the zooplankton community (34\% being naupliar stages) in Três Marias and 62.5\% (38.4\% naupliar stages) in Furnas. Rotifera comprised $40.1 \%$ and $20.6 \%$, respectively. Cladocera comprised 9.3\% in Três Marias and $16.9 \%$ in Furnas (Brito et al., 2011). Mean densities of microcrustacean species considered in this study, during all the seasons sampled, are presented in Figure 2.

Mean length $(\mathrm{mm})$ and respective mean dry weight $(\mu \mathrm{gDW})$ of developmental stages of the main microcrustacean species in Três Marias and Furnas reservoirs are presented in Table 2. For the species that occur in both reservoirs, generally shorter lengths were observed in Três Marias (t-values for C. cornuta $=7.776 ; M$. minuta $=6.891$ and $T$. minutus $=4.343 ; \mathrm{p}<0.0001)$, with the exceptions of $B$. deitersi $(\mathrm{t}=0.965 ; \mathrm{p}=0.341)$ and $B$. hagmanni $(\mathrm{t}=0.824 ; \mathrm{p}=0.414)$, where differences were not significant. Lower dry weights were also obtained in Três Marias, but differences were not significant for bosminids $(\mathrm{t}=1.561 ; \mathrm{p}=0.127$ and $\mathrm{t}=1.347 ; \mathrm{p}=0.249$ respectively).

Length-weight regressions obtained in this study (Table 3) were considered adequate for dry weight estimates of copepod and cladoceran species from Três Marias and Furnas reservoirs, since the differences between the observed and estimated weights were not significant ( $\mathrm{p} \geq 0.928$ ). Comparing common species, regressions obtained for $T$. minutus, B. hagmanni, and $M$. minuta from Furnas were characterized by a steeper slope (b value), indicating a greater increase in dry weight for an individual of the same length in Três Marias Reservoir. Steeper slopes in the regressions of $B$. deitersi and C. cornuta were obtained in Três Marias.

As observed for the density, microcrustacean biomass (see Figure 2) showed seasonal variations, with higher values recorded in the rainy season $(\mathrm{F}=131.81$; $\mathrm{p}=0.000$ ) (mean values in dry and rainy seasons of $3.75 \mathrm{mg}$ DW. $\mathrm{m}^{-3}$ and $18.14 \mathrm{mg}$ DW. $\mathrm{m}^{-3}$ in Três Marias and $5.76 \mathrm{mg} \mathrm{DW} . \mathrm{m}^{-3}$ and $20.36 \mathrm{mg}$ DW.m $\mathrm{m}^{-3}$ in Furnas, respectively). However, differently from density, higher values of microcrustacean biomass were observed in Furnas $(F=2.808 ; p=0.04)$. Higher values of biomass in Três Marias were obtained in the Barrão arm, and in Furnas, in the Mendonça arm, but the differences were not significant $(\mathrm{p}>0.06)$. Copepods always comprised the majority of microcrustacean biomass in both reservoirs, between 68 and $80 \%$ in Três Marias and between 53 and $75 \%$ in Furnas.

In Três Marias Reservoir, T. minutus is the most important species in density and biomass $(\mathrm{F}=12.16$; $\mathrm{p}<0.0001$ ) with mean values in the dry and rainy seasons of $2.81 \mathrm{mg} \mathrm{DW} . \mathrm{m}^{-3}$ and $14.29 \mathrm{mg}$ DW. $\mathrm{m}^{-3}$, respectively. In Furnas the values were $1.31 \mathrm{mg}$ DW. $\mathrm{m}^{-3}$ and $7.10 \mathrm{mg}$ $\mathrm{DW} . \mathrm{m}^{-3}$, respectively. In this reservoir, other species such as $N$. henseni (mean values in the dry season: 2.43 $\mathrm{mg}$ DW. $\mathrm{m}^{-3}$ and in the rainy season: $6.78 \mathrm{mg} \mathrm{DW} . \mathrm{m}^{-3}$ ), D. ambigua (mean values in the dry season: $0.92 \mathrm{mg}$ DW. $\mathrm{m}^{-3}$ and in the rainy season: $1.61 \mathrm{mg}$ DW. $\mathrm{m}^{-3}$ ), also made important contributions to the biomass (Table 4). Bosminopsis deitersi, B. hagmanni, and M. minuta showed higher values of biomass in Três Marias (mean values: $0.41,1.25$, and $0.42 \mathrm{mg} \mathrm{DW} . \mathrm{m}^{-3}$, respectively) than in Furnas $\left(0.03,0.22\right.$, and $0.26 \mathrm{mg} \mathrm{DW} . \mathrm{m}^{-3}$ ) $(\mathrm{F}=5.77 ; \mathrm{p}<0.005)$; whereas $C$. cornuta was more important in Furnas, with $0.47 \mathrm{mg}$ DW. $\mathrm{m}^{-3}$ and $0.32 \mathrm{mg}$ DW. $\mathrm{m}^{-3}$ in Três Marias $(\mathrm{F}=4.57 ; \mathrm{p}<0.005)$. The largersized species $C$. silvestrii, D. spinulosum, and $D$. fluviatile (means $0.36,0.18$, and $0.04 \mathrm{mg} \mathrm{DW} . \mathrm{m}^{-3}$ in the dry season and $1.25,0.82$, and $1.12 \mathrm{mg} \mathrm{DW} . \mathrm{m}^{-3}$ in the rainy season, respectively) also contributed to a higher cladoceran biomass in Furnas Reservoir.

Considering the cladoceran species in Três Marias Reservoir, B. hagmanni was the most important species in terms of biomass, especially in the rainy season (be- 

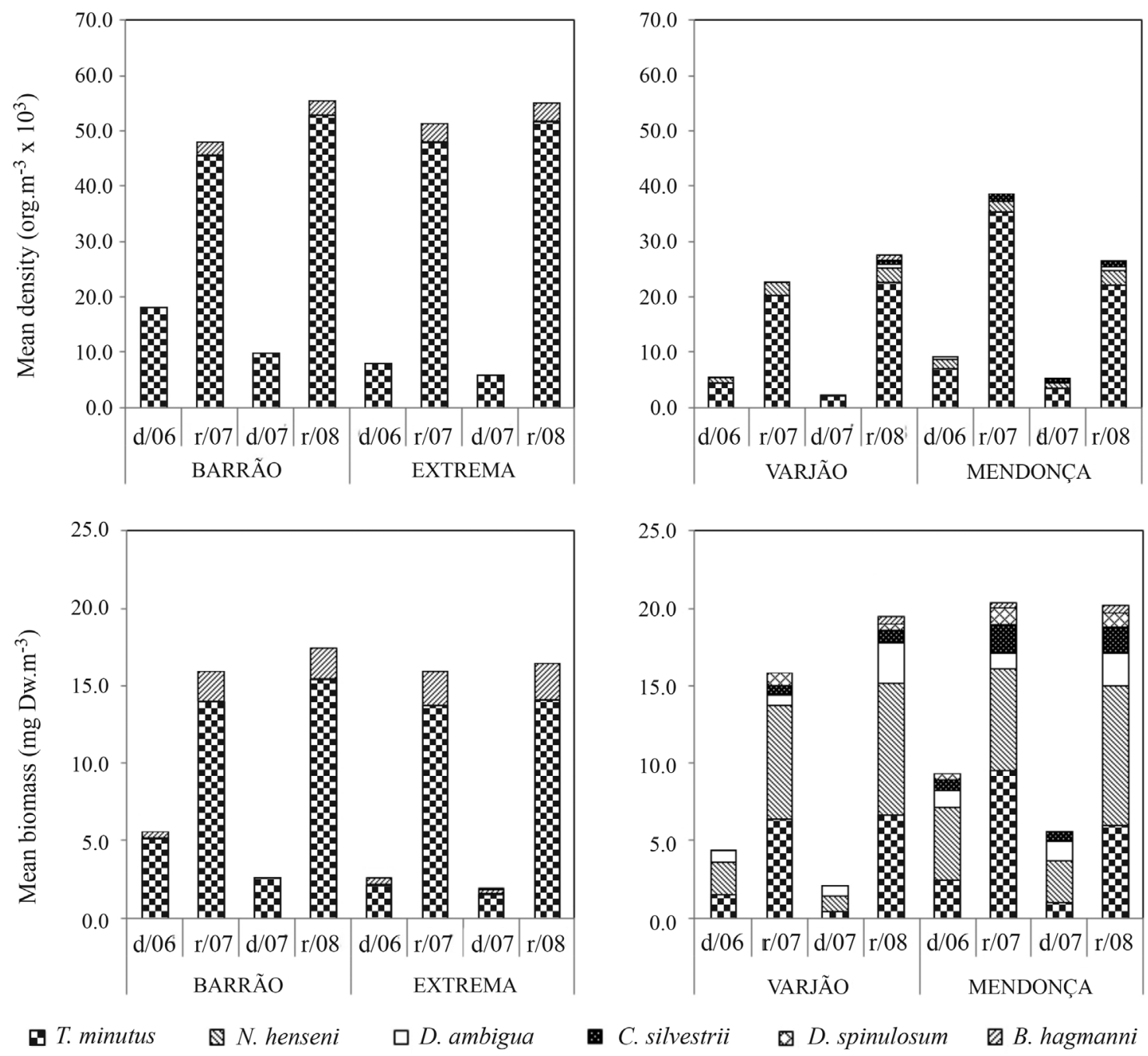

Figure 2 - Mean density (org. $\left.\mathrm{m}^{-3} \cdot 10^{3}\right)$ and mean values of biomass $\left(\mathrm{mg}\right.$ DW. $\mathrm{m}^{-3}$ ) of the main microcrustacean species of Três Marias (Barrão and Extrema arms, right) and Furnas (Varjão and Mendonça arms, left). d/06 = dry season 2006, r/07 = rainy season $2007, \mathrm{~d} / 07=$ dry season 2007 , and r/08 = rainy season 2008. For Copepoda species, include nauplii, copepodids, and adults.

tween 50 and $68 \%$ of cladoceran biomass), followed by C. cornuta (ca. 16.3\%) and M. minuta (ca. 20.8\%). In the dry season, this scenario changed, with $B$. deitersi contributing most to the biomass (between 33 and $52 \%$ ). In Furnas, D. ambigua was usually the most important species (between 29 and 56\% of cladoceran biomass), and other daphniids and sidids including C. silvestrii (up to $24.9 \%$ ), C. cornuta (up to $20.4 \%$ ), D. spinulosum (up to $20.6 \%$ ), and $D$. fluviatile (up to $25.4 \%$ ) were more important in the rainy season. Bosminids did not reach levels higher than $0.49 \mathrm{mg}$ DW.m $\mathrm{m}^{-3}$ (9\% of cladoceran biomass).

\section{Discussion}

Body-size and dry-weight values obtained for the microcrustacean species in Três Marias and Furnas reser- voirs were within the range of those obtained by several investigators in other Brazilian aquatic ecosystems. Considering differences in methodology, the following studies did not mentioned or did not make corrections for losses due to preservation: Maia-Barbosa (2000); MaiaBarbosa and Bozelli (2005); Sendacz et al. (2006); González et al. (2008); Magalhães et al. (2006); Blettler and Bonecker (2007); Rosa (2008); Rocha and MatsumuraTundisi (1984). Some studies used allometric equations: Corgosinho and Pinto-Coelho, 2006; Pinto-Coelho et al., 2005a. Others studies used fresh animals to determine the weight: Castilho-Noll and Arcifa (2007); MatsumuraTundisi et al. (1989); Melão et al. (2005); Melão and Rocha (2006); Santos et al. (2006).

Compared with the mean dry weights obtained for $B$. hagmanni, B. deitersi, C. cornuta, and $M$. minuta in Lake Batata (PA - state of Pará) by Maia-Barbosa and Bozelli 
Table 2 - Mean length $(\mathrm{mm})$, mean dry weight ( $\mu \mathrm{g} \mathrm{DW})$, and number of replicates for the main microcrustacean species of Três Marias and Furnas reservoirs (Minas Gerais).

\begin{tabular}{|c|c|c|c|c|c|c|}
\hline & \multicolumn{3}{|c|}{ Três Marias } & \multicolumn{3}{|c|}{ Furnas } \\
\hline & $\mathbf{m m}$ & $\mu \mathrm{gDW}$ & $\mathbf{n}$ & $\mathbf{m m}$ & $\mu \mathrm{gDW}$ & n \\
\hline Thermocyclops minutus - nauplii & 0.112 & 0.232 & 28 & 0.116 & 0.210 & 28 \\
\hline Thermocyclops minutus - copepodid I-III & 0.270 & 0.318 & 28 & 0.299 & 0.396 & 27 \\
\hline Thermocyclops minutus - copepodid IV-V & 0.396 & 0.432 & 28 & 0.418 & 0.536 & 26 \\
\hline Thermocyclops minutus - male & 0.421 & 0.457 & 27 & 0.445 & 0.548 & 28 \\
\hline Thermocyclops minutus - female & 0.496 & 0.563 & 27 & 0.511 & 0.733 & 25 \\
\hline Notodiaptomus henseni - nauplii & & & & 0.274 & 0.846 & 27 \\
\hline Notodiaptomus henseni- copepodid I-III & & & & 0.520 & 1.283 & 28 \\
\hline Notodiaptomus henseni- copepodid IV-V & & & & 0.868 & 3.225 & 28 \\
\hline Notodiaptomus henseni- male & & & & 1.068 & 4.325 & 28 \\
\hline Notodiaptomus henseni- female & & & & 1.136 & 5.244 & 28 \\
\hline Daphnia ambigua - neonate & & & & 0.604 & 0.957 & 27 \\
\hline Daphnia ambigua - juvenile & & & & 0.824 & 2.016 & 27 \\
\hline Daphnia ambigua - adult & & & & 1.112 & 4.174 & 26 \\
\hline Ceriodaphnia silvestrii - neonate & & & & 0.375 & 0.799 & 25 \\
\hline Ceriodaphnia silvestrii- juvenile & & & & 0.491 & 1.183 & 25 \\
\hline Ceriodaphnia silvestrii- adult & & & & 0.640 & 2.010 & 26 \\
\hline Ceriodaphnia cornuta - neonate & 0.212 & 0.250 & 28 & 0.274 & 0.420 & 25 \\
\hline Ceriodaphnia cornuta- juvenile & 0.251 & 0.341 & 26 & 0.331 & 0.513 & 23 \\
\hline Ceriodaphnia cornuta- adult & 0.317 & 0.485 & 27 & 0.414 & 0.718 & 23 \\
\hline Moina minuta - neonate & 0.282 & 0.348 & 27 & 0.348 & 0.498 & 21 \\
\hline Moina minuta - juvenile & 0.320 & 0.448 & 26 & 0.402 & 0.616 & 22 \\
\hline Moina minuta - adult & 0.391 & 0.513 & 28 & 0.515 & 0.851 & 26 \\
\hline Diaphanosoma spinulosum - neonate & & & & 0.467 & 0.710 & 24 \\
\hline Diaphanosoma spinulosum - juvenile & & & & 0.609 & 1.260 & 20 \\
\hline Diaphanosoma spinulosum - adult & & & & 0.783 & 1.668 & 26 \\
\hline Diaphanosoma fluviatile - neonate & & & & 0.390 & 0.510 & 26 \\
\hline Diaphanosoma fluviatile - juvenile & & & & 0.479 & 0.794 & 26 \\
\hline Diaphanosoma fluviatile - adult & & & & 0.604 & 1.127 & 27 \\
\hline Bosmina freyi - neonate & & & & 0.222 & 0.369 & 18 \\
\hline Bosmina freyi - juvenile & & & & 0.252 & 0.622 & 23 \\
\hline Bosmina freyi - adult & & & & 0.314 & 0.804 & 24 \\
\hline Bosmina hagmanni - neonate & 0.206 & 0.608 & 25 & 0.224 & 0.348 & 25 \\
\hline Bosmina hagmanni - juvenile & 0.265 & 0.705 & 28 & 0.274 & 0.503 & 27 \\
\hline Bosmina hagmanni-adult & 0.348 & 0.810 & 27 & 0.341 & 0.747 & 28 \\
\hline Bosminopsis deitersi - neonate & 0.193 & 0.290 & 26 & 0.204 & 0.247 & 19 \\
\hline Bosminopsis deitersi - juvenile & 0.245 & 0.457 & 25 & 0.240 & 0.394 & 20 \\
\hline Bosminopsis deitersi - adult & 0.289 & 0.600 & 26 & 0.289 & 0.473 & 24 \\
\hline
\end{tabular}

(2005), individuals in Três Marias and Furnas showed higher values than those estimated for cladocerans from the "natural" (unimpacted) station of that lake, however lower values than observed at the station in the area impacted by bauxite tailings. According to these authors, the ingestion of tailing particles and the retention of this material within the valves (imposible to remove during preparation for weighing) is the reason for the higher weight of individuals from the impacted station.

Daphnia ambigua showed a larger mean body size, however a lower mean dry weight than observed by Castilho-Noll and Arcifa (2007) in Lake Monte Alegre 
Table 3 - Length ( $\operatorname{Ln} \mu \mathrm{gDW})$ - Weight ( $\mathrm{Ln} \mathrm{mm}$ ) relationships for the main microcrustacean species of Três Marias and Furnas reservoirs (Minas Gerais).

\begin{tabular}{llc}
\hline Três Marias & & $\mathbf{R}^{2}$ \\
\hline Thermocyclops minutus & $\mathrm{LnW}=-0.2886+0.5609 \mathrm{LnL}$ & 0.935 \\
Bosminopsis deitersi & $\mathrm{LnW}=1.843+1.844 \mathrm{LnL}$ & 0.702 \\
Bosmina hagmanni & $\mathrm{LnW}=1.087+1.086 \mathrm{LnL}$ & 0.736 \\
Ceriodaphnia cornuta & $\mathrm{LnW}=1.310+1.772 \mathrm{LnL}$ & 0.717 \\
Moina minuta & $\mathrm{LnW}=0.3546+1.093 \mathrm{LnL}$ & 0.732 \\
\hline Furnas & & $\mathrm{R}^{2}$ \\
\hline Thermocyclops minutus & $\mathrm{LnW}=0.0922+0.7849 \mathrm{LnL}$ & 0.971 \\
Notodiaptomus henseni & $\mathrm{LnW}=1.334+1.102 \mathrm{LnL}$ & 0.936 \\
Daphnia ambigua & $\mathrm{LnW}=1.169+2.418 \mathrm{LnL}$ & 0.921 \\
Ceriodaphnia silvestrii & $\mathrm{LnW}=1.450+1.760 \mathrm{LnL}$ & 0.798 \\
Ceriodaphnia cornuta & $\mathrm{LnW}=0.9936+1.524 \mathrm{LnL}$ & 0.721 \\
Moina minuta & $\mathrm{LnW}=0.7458+1.428 \mathrm{LnL}$ & 0.723 \\
Diaphanosoma spinulosum & $\mathrm{LnW}=0.9568+1.669 \mathrm{LnL}$ & 0.922 \\
Diaphanosoma fluviatile & $\mathrm{LnW}=1.111+1.892 \mathrm{LnL}$ & 0.886 \\
Bosmina freyi & $\mathrm{LnW}=2.127+2.002 \mathrm{LnL}$ & 0.778 \\
Bosmina hagmanni & $\mathrm{LnW}=1.778+1.916 \mathrm{LnL}$ & 0.890 \\
Bosminopsis deitersi & $\mathrm{LnW}=1.523+1.807 \mathrm{LnL}$ & 0.800 \\
\hline
\end{tabular}

Table 4 - Mean values of biomass $\left(\mathrm{mg}\right.$ DW. $\left.\mathrm{m}^{-3}\right)$ of the main microcrustacean species of Três Marias and Furnas reservoirs (Minas Gerais). d/06 = dry season 2006, r/07 = rainy season 2007, d/07 = dry season 2007, and r/08 = rainy season 2008.

\begin{tabular}{|c|c|c|c|c|c|c|c|c|}
\hline \multirow[t]{2}{*}{ Três Marias } & \multicolumn{4}{|c|}{ Barrão } & \multicolumn{4}{|c|}{ Extrema } \\
\hline & $d / 06$ & $\mathbf{r} / \mathbf{0 7}$ & $\mathrm{d} / \mathbf{0 7}$ & $\mathbf{r} / 08$ & $\mathrm{~d} / \mathbf{0 6}$ & $\mathbf{r} / \mathbf{0 7}$ & d/07 & $\mathbf{r} / \mathbf{0 8}$ \\
\hline Thermocyclops minutus & 5.09 & 13.96 & 2.57 & 15.39 & 2.08 & 13.70 & 1.50 & 14.10 \\
\hline Bosminopsis deitersi & 0.77 & 0.30 & 0.43 & 0.53 & 0.51 & 0.20 & 0.14 & 0.43 \\
\hline Bosmina hagmanni & 0.45 & 2.00 & 0.28 & 2.00 & 0.38 & 2.20 & 0.22 & 2.36 \\
\hline Ceriodaphnia cornuta & 0.17 & 0.52 & 0.09 & 0.68 & 0.06 & 0.69 & 0.04 & 0.36 \\
\hline Moina minuta & 0.10 & 0.81 & 0.08 & 0.71 & 0.05 & 0.91 & 0.03 & 0.69 \\
\hline Furnas & \multicolumn{4}{|c|}{ Varjão } & \multicolumn{4}{|c|}{ Mendonça } \\
\hline Thermocyclops minutus & 1.46 & 6.38 & 0.42 & 6.59 & 2.40 & 9.53 & 0.95 & 5.95 \\
\hline Notodiaptomus henseni & 1.95 & 6.54 & 0.91 & 7.59 & 4.42 & 4.99 & 2.43 & 8.06 \\
\hline Daphnia ambigua & 0.74 & 0.74 & 0.67 & 2.61 & 1.06 & 1.05 & 1.19 & 2.06 \\
\hline Ceriodaphnia silvestrii & 0.11 & 0.56 & 0.05 & 0.85 & 0.69 & 1.86 & 0.60 & 1.73 \\
\hline Ceriodaphnia cornuta & 0.14 & 0.61 & 0.09 & 0.54 & 0.18 & 1.53 & 0.08 & 0.62 \\
\hline Moina minuta & 0.25 & 0.22 & 0.12 & 0.56 & 0.18 & 0.26 & 0.09 & 0.40 \\
\hline Diaphanosoma spinulosum & 0.12 & 0.88 & 0.02 & 0.48 & 0.39 & 1.04 & 0.20 & 0.87 \\
\hline Diaphanosoma fluviatile & 0.04 & 1.09 & 0.03 & 1.21 & 0.04 & 1.48 & 0.05 & 0.50 \\
\hline Bosmina freyi & 0.12 & & 0.10 & 0.31 & 0.26 & & 0.11 & 0.42 \\
\hline Bosmina hagmanni & 0.08 & 0.19 & 0.03 & 0.49 & 0.10 & 0.31 & 0.06 & 0.46 \\
\hline Bosminopsis deitersi & 0.02 & & 0.08 & & 0.01 & & 0.02 & \\
\hline
\end{tabular}


(state of São Paulo) (mean dry weights of small, medium, and large individuals: 1.45, 4.64, and $8.27 \mu \mathrm{g}$, respectively). Lake Monte Alegre is considered an eutrophic environment, and therefore individuals of this species may have a better nutritional condition and consequently higher dry weight. However, dry weight values near those obtained in this study were observed by Sendacz et al. (2006) in both Ponte Nova (oligotrophic) and Guarapiranga reservoirs (eutrophic) (São Paulo).

Bosminopsis deitersi showed a smaller mean body size and lower mean dry weight compared to adults in Broa $(0.61 \mu \mathrm{g})$ (Matsumura-Tundisi et al., 1989) and Lagoa Dourada reservoirs (Melão and Rocha, 2006) (dry weights of neonates, juveniles, and adults: $0.23,0.55$, and $0.70 \mu \mathrm{g}$, respectively). However, comparisons with these environments must be made with care, because nonpreserved individuals were used.

Moina minuta, Ceriodaphnia cornuta, and $C$. silvestrii from Três Marias and Furnas reservoirs showed lower mean dry weights compared to Ponte Nova and Guarapiranga reservoirs (Sendacz et al., 2006); however, the last species showed higher values than those obtained by González et al. (2008) for Bariri Reservoir (SP) (mean dry weight of adults: $1.44 \mu \mathrm{g}$ ). Length and dry weight of C. silvestrii found by Santos et al. (2006) (dry weights for neonates, juveniles, and adults of 1.337, 2.113, and 5.335 $\mu \mathrm{g}$, respectively) were higher than those obtained in Três Marias and Furnas. However, the indivuduals of this study were raised in the laboratory, and their weights were estimated from non-preserved individuals. In Bariri Reservoir, Diaphanosoma spinulosum and Bosmina hagmanni showed higher mean dry weights for adults (1.897 and $2.233 \mu \mathrm{g}$, respectively) (González et al., 2008). In Broa Reservoir (Matsumura-Tundisi et al., 1989), copepodids (I-V) $(420 \mu \mathrm{m}$ and $0.430 \mu \mathrm{g})$ and males and females $(600 \mu \mathrm{m}$ and $0.780 \mu \mathrm{g})$ of Thermocyclops minutus showed larger body sizes and higher mean dry weights than observed in Três Marias and Furnas reservoirs. For this species also, non-preserved individuals were measured.

These differences among the estimates of body size and dry weight for microcrustaceans reflect the responses of species to the varied conditions in aquatic ecosystems (Dumont et al., 1975; Boersma and Vijverberg, 1996; Blettler and Bonecker, 2006).

Length-weight relationships for microcrustacean species were confirmed in the present study. Some studies have failed to find linearity in this relationship (Magalhães et al., 2006; González et al., 2008). However, these authors did not use logarithmic transformation, a procedure that strengthens length-weight relationships due to linearization of the data (Blettler and Bonecker, 2006).

Biomass fluctuations in Três Marias and Furnas reservoirs were more pronounced in the rainy season, as also observed by Rosa (2008) in five reservoirs of the Furnas Centrais Elétricas S.A. System and by Melão et al. (2005) in Lagoa Dourada Reservoir. In some studies, higher values were obtained in the dry season (Rocha and Matsu-
mura-Tundisi, 1984; Sendacz et al., 2006, Santos-Wisniewski and Rocha, 2007); while in others, this pattern most often was not evident, due to different contributions of zooplankton groups in the two seasons (Rietzler et al., 2004; Corgosinho and Pinto-Coelho, 2006). However, in all studies, the highest values of biomass were consistently related to sites and seasons with higher food availability (nutrients, chlorophyll- $a$, suspended solids). In fact, in Três Marias and Furnas reservoirs, higher values of chlorophyll- $a$ and suspended solids were observed in the rainy season (Brito et al., 2011). However, significant correlations with microcrustacean biomass were obtained only for total and organic suspended solids $(\mathrm{r}=0.560$ and $0.547 ; \mathrm{p}<0.0001 ;$ respectively). In these reservoirs, this could be an important non-algal food source for the species studied. According to Marzolf (1990), the phytoplankton alone does not satisfy all the nutritional requirements of zooplankton. Pinto-Coelho et al. (2005a and 2005b) suggested that when the correlations between chlorophyll- $a$ and zooplankton biomass are weak, detritus is more important than primary production.

The dominance of $T$. minutus in density and biomass in Três Marias can be explained by the predominant food available in this reservoir, the cyanobacteria. This copepod species can capture large cyanobacteria colonies such as Microcystis, Botryococcus, and Aphanocapsa (Matsumura-Tundisi et al., 1997). However, because cyanobacteria have low nutritional value (Rietzler and Espíndola, 1998), the greater consumption of this group by T. minutus in Três Marias can affect its development, resulting in smaller-sized individuals and lower dry weight than for the same species in Furnas Reservoir.

Higher biomass values in Furnas may be related to larger-bodied species such as calanoids ( $N$. henseni), daphniids (D. ambigua and $C$. silvestrii), and sidids ( $D$. spinulosum and $D$. fluviatile), which have higher dry weights than the smaller bosminids that predominate in Três Marias. Castilho-Noll and Arcifa (2007) observed that, despite its smaller body size, D. ambigua weighed more than $D$. gessneri, probably due to its rounded body shape, reflecting a higher biomass. Similarly, for $B$. hagmanni in Três Marias, the higher dry weight of this species resulted in a higher biomass contribution than $B$. deitersi, which dominated in numbers. Therefore, we can conclude that for microcrustaceans, biomass better represents the community structure than does numerical density alone.

The microcrustacean biomass values estimated in Três Marias and Furnas reservoirs are close to those observed in other reservoirs considered oligotrophic such as Segredo and Mourão (Blettler and Bonecker, 2007) in state of Paraná; Ponte Nova (Sendacz et al., 2006) and Lagoa Dourada (Melão et al., 2005) in São Paulo. In the natural lakes Dom Helvécio and Carioca (Minas Gerais) these values also were close to these oligotrophic reservoirs (Table 5).

In Lake Batata, lower cladoceran biomass values occured at the natural station, while at the station im- 
pacted by bauxite tailings, higher biomass values - close to mesotrophic environments - were recorded. In Broa Reservoir, microcrustacean biomass showed peaks from 60 to $80 \mathrm{mg} \mathrm{DW} \cdot \mathrm{m}^{-3}$ (Matsumura-Tundisi et al., 1989) when the study was carried out, this reservoir was considered mesotrophic by authors.

Eutrophic reservoirs as Iraí in Paraná (Bletter and Bonecker, 2007) Barra Bonita (Santos-Wisniewski et al., 2002), Salto Grande (Rietzler et al., 2004) and Guarapiranga (Sendacz et al., 2006) in São Paulo and Pampulha, an urban reservoir in Minas Gerais (Pinto-Coelho et al., 2005a) generally show biomass values that ranged from tens to hundreds (Table 5). In Monjolinho (SP), considered meso-eutrophic, Okano (unpublished data) found mean values of biomass up to thousands: $4.008 \mathrm{gDW} . \mathrm{m}^{-3}$ for Cladocera and $2.560 \mathrm{gDW} . \mathrm{m}^{-3}$ for Copepoda.

In naturally eutrophic environments such as Lake Amarela $\left(Z_{\max }=2 \mathrm{~m}\right.$, in the final stage of succession, and densely colonized by macrophytes), higher biomass values were also obtained, with an annual mean of 173.85 $\mathrm{mg} \mathrm{DW} \cdot \mathrm{m}^{-3}$ for microcrustaceans (Matsumura-Tundisi and Tundisi, 1986).

Several authors have described a positive relationship between zooplankton biomass and the trophic state of tropical and temperate aquatic environments (Pederson et al., 1976; Pace, 1986; Esteves and Sendacz, 1988; Rocha et al., 1995; Rocha et al., 1997; Pinto-Coelho et al., 2005c). These authors considered differences in phytoplankton quantity and quality as the food source, and in zooplankton community composition and density among environments, as well as the nutritional state of individuals and other factors that influence biomass.

Although they are both considered oligotrophic, Três Marias and Furnas reservoirs showed remarkable differences in microcrustacean biomass. In Três Marias, Thermocyclops minutus, a common species in Brazilian

Table 5 - Mean values os microcrustaceans biomass $\left(\mathrm{mg} \mathrm{DW} \cdot \mathrm{m}^{-3}\right)$ in several lakes and reservoirs of Brazil considering their trophic state. * According to the authors of each manuscript.

\begin{tabular}{|c|c|c|c|}
\hline Reservoir or Lake & Range (mg DW.m-3) & Authors & Trophic state* \\
\hline \multirow[t]{2}{*}{ Três Marias (MG) } & Cladocera: $0.43-4.00$ & this study & \\
\hline & Copepoda: $1.50-15.39$ & & \\
\hline \multirow[t]{2}{*}{ Furnas (MG) } & Cladocera: 1.19-7.59 & this study & \\
\hline & Copepoda: $1.43-16.07$ & & \\
\hline Segredo and Mourão (PR) & Microcrustaceans: $0.03-20.26$ & Bletter \& Bonecker, 2007 & \\
\hline \multirow[t]{2}{*}{ Ponte Nova (SP) } & Cladocera: 9.264-9.794 & Sendacz et al., 2006 & oligotrophic \\
\hline & Copepoda: $0.357-1.657$ & & \\
\hline \multirow[t]{2}{*}{ Lagoa Dourada (SP) } & Cladocera: 3.496-10.037 & Melão et al., 2005 & \\
\hline & Copepoda: $0.852-5.956$ & & \\
\hline $\begin{array}{l}\text { Dom Helvécio and Carioca } \\
\text { (MG) }\end{array}$ & $\begin{array}{l}\text { Microcrustaceans: } 26.57 \text { and } \\
10.88 \text {, respectively }\end{array}$ & Matsumura -Tundisi \& Tundisi, 1986 & \\
\hline Lago Batata (PA) & natural station: $2.69-11.04$ & Maia-Barbosa, 2000 & \\
\hline Lago Batata (PA) & impacted station: $24.61-38.9$ & Maia-Barbosa, 2000 & \\
\hline \multirow[t]{2}{*}{ Broa (SP) } & Microcrustaceans: $10-15$ & Matsumura-Tundisi et al., 1989 & mesotrophic \\
\hline & peaks $60-80$ & & \\
\hline Iraí (PR) & Microcrustaceans: 7.14-261.52 & Bletter \& Bonecker, 2007 & \\
\hline \multirow[t]{2}{*}{ Salto Grande (SP) } & Cladocera: $21.4-122.5$ & Rietzler et al., 2004 & \\
\hline & Copepoda: $117.0-319.0$ & & \\
\hline \multirow[t]{2}{*}{ Guarapiranga (SP) } & Cladocera: $37.72-69.59$ & Sendacz et al., 2006 & \\
\hline & Copepoda: $6.48-236.18$ & & eutrophic \\
\hline \multirow[t]{2}{*}{ Pampulha (MG) } & Cladocera: 40.42-572.16 & Pinto-Coelho et al., 2005 & \\
\hline & Copepoda: 11.34-379.51 & & \\
\hline Barra Bonita (SP) & Microcrustaceans: $50-100$ & Santos-Wisniewski et al., 2002 & \\
\hline Amarela (MG) & Microcrustaceans: 173.85 & Matsumura -Tundisi \& Tundisi, 1986 & \\
\hline \multirow[t]{2}{*}{ Monjolinho (SP) } & Cladocera: 4008 & Okano, 1994 & \\
\hline & Copepoda: 2560 & & \\
\hline
\end{tabular}


aquatic environments (Reid, 1989) was the most important in terms of density, and comprised up to $80 \%$ of the biomass. Bosminopsis deitersi, B. hagmanni, C. cornuta, and $M$. minuta were not important in this reservoir, in contrast to other Brazilian lakes and reservoirs (MaiaBarbosa, unpublished data; Melão and Rocha, 2006; Sendacz et al., 2006). In Furnas, copepods were also the dominant group in density and biomass; however, $N$. henseni contributed in the same proportion as T. minutus. The higher Cladocera biomass in this reservoir was composed mainly of the larger-sized species $D$. ambigua, $C$. silvestrii, D. spinulosum, and D. fluviatile, especially during the rainy season. Because of their greater availability in terms of biomass and higher nutritional quality (Santeiro and Pinto-Coelho, 2000; Pinto-Coelho et al., 2005a), larger-sized microcrustaceans may be considered a more appropriate food source for juveniles as well as adults of zooplanktivorous fishes in Furnas Reservoir.

\section{Acknowledgments}

To the staff of the Zooplankton Ecology Laboratory, the Laboratory of Environmental Management of Reservoirs, and the Limnology Laboratory, who directly or indirectly helped make this study possible. This work was supported by the Technical-Scientific Study for the Delimit Aquaculture Areas in the Lakes of Furnas and Três Marias Reservoirs - MG, Brazil (Agreement 8713 - Special Secretariat of Aquaculture and Fishery; State Secretariat for Science, Technology and Higher Education; Research Development Foundation - Federal University of Minas Gerais) and National Counsel of Technological and Scientific Development, grant number $142079 / 2006-5$ to S.L.B. that financed this research.

\section{References}

BEZERRA NETO, JF. and PINTO-COELHO, RM., 2002. Population dynamics and secondary production of Chaoborus brasiliensis (Diptera: Chaoboridae) in a small tropical reservoir: Lagoa do Nado, Minas Gerais - Brazil. Acta Limnologica Brasiliensia, vol. 14, p. 61-72.

BIRD, DF. and PRAIRE, YT., 1985. Practical guidelines for the use of zooplankton length-weight regression equations. Journal of Plankton Research, vol. 7, p. 955-960.

BLETTLER, MCM. and BONECKER, CC., 2006. Avaliação da Biomassa de Microcrustáceos em Ambientes Aquáticos Continentais. Interciencia, vol. 31, p. 591-597.

BLETTLER, MCM. and BONECKER, CC., 2007. Longitudinal distribution of microcrustacean biomass in three tropical reservoirs (Paraná State, Brazil). Acta Scientiarum: Biological Sciences, vol. 29, p. 297-304.

BOERSMA, M. and VIJVERBERG, J., 1996. Food effects on life history traits and seasonal dynamics of Ceriodaphnia pulchella. Freshwater Biolology, vol. 35, p. 25-34.

BONECKER, CC., NAGAE, MY., BLETTLER, MCM., VELHO, LFM. and LANSAC-TÔHA, FA., 2007. Zooplankton biomass in tropical reservoirs in southern Brazil. Hydrobiologia, vol. 579, p. 115-123.

BOTTRELL, HH., DUNCAN, A., GLIWICZ, ZM., GRYGIEREK, E., HERZIG, A., HILLBRICHT-ILKOWSKA, A., KURASAUA, H., LARSSON, P., WEGLENSKA, T., 1976. A review of some problems in zooplankton produc- tion studies. Norway Journal of Zoology, vol. 24, p. 419456.

BOZELLI, RL. and HUSZAR, VLM., 2003. Comunidades Fito e Zooplanctônicas Continentais em Tempo de Avaliação. LIMNOtemas, vol. 3, p. 1-32.

BRITO, SL., MAIA-BARBOSA, PM. and PINTO-COELHO, RM., 2011. Zooplankton as an indicator of trophic conditions in two large reservoirs in Brazil. Lakes and Reservoirs: Research and Management, vol. 16, p. 253-264.

CASTILHO-NOLL, MSM. and ARCIFA, MS., 2007. Lengthweight relationships for zooplanktonic species of a tropical Brazilian lake: Lake Monte Alegre. Acta Limnologica Brasiliensia, vol. 19, p. 93-100.

CEMIG, 2012. Hydroelectric Dams of CEMIG. Available from: http://www.cemig.com.br/NossosNegocios/Paginas/usin as.aspx. Access in: 04 Feb. 2012.

CORGOSINHO, PHC. and PINTO-COELHO, RM., 2006. Zooplankton biomass, abundance and allometric patterns along an eutrophic gradient at Furnas Reservoir (Minas Gerais, Brazil). Acta Limnologica Brasiliensia, vol. 18, p. 213-224.

DUMONT, HJ., VAN DE VELDE, I. and DUMONT, S., 1975. The Dry Weight Estimate of Biomass in a Selection of Cladocera, Copepoda and Rotifera from the Plankton Peryphyton and benthos of Continental Waters. Oecologia, vol. 19, p. 75-97.

ESTEVES, KE. and SENDACZ, S., 1988. Relações entre a biomassa do zooplâncton e o estado trófico de reservatórios do Estado de São Paulo. Acta Limnologica Brasiliensia, vol. 11, p. 587-604.

FURNAS, 2012. Furnas Hydroelectric System. Available from: http://www.furnas.com.br/hotsites/sistemafurnas. Access in February 4, 2012.

GONZÁLEZ, EJ., MATSUMURA-TUNDISI, T. and TUNDISI, JG., 2008. Size and dry weight of main zooplankton species in Bariri reservoir (SP, Brazil). Brazilian Journal of Biology, vol. 68, p. 69-75.

LÓPEZ, CM. and SAMPAIO, EV., 2003. A comunidade zooplanctônica no reservatório de Três Marias e no trecho do São Francisco a jusante. In GODINHO, HP., GODINHO, AL. (Eds.). Águas, Peixes e Pescadores do São Francisco das Minas Gerais. Belo Horizonte: PUCMinas. p. 93-104.

MAGALHÃES, A., COSTA, RM., LIANG, TH. and PEREIRA, LCC., RIBEIRO, MJS., 2006. Spatial and Temporal Distribution in Density and Biomass of Two Pseudodiaptomus Species (Copepoda: Calanoida) in the Caeté River Estuary (Amazon Region - North of Brazil). Brazilian Journal of Biology, vol. 66, p. 421-430.

MAIA-BARBOSA, PM., 2000. Ecologia de Cinco Espécies de Cladóceros de um Lago Amazônico Impactado por Rejeito de Bauxita (Lago Batata, Pará-Brasil). Rio de Janeiro: Universidade Federal do Rio de Janeiro. 218 p. Tese de Doutorado em Ecologia.

MAIA-BARBOSA, PM., BOZELLI, R., 2005. Length-Weight Relationships for Five Cladoceran Species in an Amazonian Lake. Brazilian Archives of Biology and Technology, vol. 48, p. 303-308.

MARZOLF, G.R., 1990. Reservoir as Environments for Zooplankton. In THORNTON, KW., KIMMEL, BL. and PAYNE, FE. (Eds.). Reservoir Limnology: Ecological Perspectives. New York: John Wiley and Sons. p. 195208.

MATSUMURA-TUNDISI, T., TUNDISI, JG., 1986. Biomass and Zooplankton Community Structure of Three Lakes of River Doce Valley (Minas Gerais - Brazil). Proceedings 
of The Fifth Japan-Brazil Symposium on Science and Tecnology, 1986. Tokyo, JPN. p. 35-43.

MATSUMURA-TUNDISI, T., RIETZLER, AC. and TUNDISI, JG., 1989. Biomass (dry weight and carbon content) of plankton crustacea from Broa reservoir (São Carlos, SP, Brazil) and its fluctuations across one year. Hydrobiologia, vol. 179, p. 229-236.

MATSUMURA-TUNDISI, T., ROCHA, O. and TUNDISI, JG., 1997. Carbon Uptake by Scolodiaptomus corderoi and Thermocyclops minutus Feeding on Different Size Fractions of Phytoplankton from Lake Dom Helvécio. In TUNDISI, JG. and SAIJO, Y. (Eds.). Limnological Studies on the Rio Doce Valley Lakes, Brazil. Rio de Janeiro: Brazilian Academy of Sciences, University of São Paulo, School of Engineering at São Carlos, Center for Water Resources and Applied Ecology. p. 275-284.

MCCAULEY, E., 1984. The estimation of the abundance and biomass of zooplankton in samples. In DOWNING, JA. and RIGLER, FH. (Eds.). A Manual on Methods for Assessment of Secondary Productivity in Freshwaters. Oxford: Blackwell Scientific Publishing. p. 228-265.

MELÃO, MG. and ROCHA, O., 2004. Life history, biomass and production of two planktonic cyclopoid copepods in a shallow subtropical reservoir. Journal of Plankton Research, vol. 26, p. 909-923.

MELÃO, MG. and ROCHA, O., 2006. Life history, population dynamics, standing biomass and production of Bosminopsis deitersi (Cladocera) in a shallow tropical reservoir. Acta Limnologica Brasiliensia, vol. 18, p. 433-450.

MELÃO, MG., ROCHA, O. and ROCHE, FK., 2005. Produtividade, Biomassa e Flutuações Populacionais e interações biológicas da Comunidade Planctônica e Suas Implicações na Transferência de Energia na Cadeia Alimentar de um Reservatório Raso e oligotrófico. In ROCHE, FK. and ROCHA, O. (Eds.). Ecologia Trófica de Peixes com ênfase na planctivoria em ambientes lênticos de água doce no Brasil. São Carlos: Rima. p. 25-80.

NOGUEIRA, DJ., CASTRO, SC. and RIGOLIN DE SÁ, O., 2008. Avaliação da qualidade da água no reservatório UHE Furnas - MG, utilizando as brânquias de Pimelodus maculatus (LACĖPÉDE, 1803) como biomarcador de poluição ambiental. Ciencia et Praxi, vol. 1, p. 15-20.

OKANO, YW., 1994. Análise da estrutura e dinâmica populacional da comunidade zooplanctônica de um reservatório artificial (reservatório Monjolinho, São Carlos, SP). São Carlos: Universidade Federal de São Carlos. 128 p. Tese de Doutorado em Ecologia e Recursos Naturais.

PACE, ML., 1986. An empirical analysis of zooplankton community size structure across lake trophic gradients. Limnology and Oceanography, vol. 31, p. 45-55.

PANARELLI, EA., CASANOVA, SMC. and HENRY, R., 2010. Secondary procudtion and biomass of Cladocera in marginal lakes after the recovery of their hydrologic connectivity in a river-reservoir trasition zone. Lakes and Reservoirs: Research and Management, vol. 15, p. 319334.

PEDERSON, GL., WELCH, EB. and LITT, AH., 1976. Plankton secondary productivity and biomass: their relation to lake trophic state. Hydrobiologia, vol. 50, p. 129-144.

PINTO-COELHO, RM., BEZERRA-NETO, JF. and MORAIS JR., CA., 2005a. Effects of Eutrophication on Size and Biomass of Crustacean Zooplankton in a Tropical Reservoir. Brazilian Journal of Biology, vol. 65, p. 325-338.

PINTO-COELHO RM., BEZERRA NETO, JF. and RULL DEL AGUILLA, LM., 2005b. The importance of Nutrient Input, Invertebrate Predation and Oxygen Deficit Gov- erning the Temporal and Spatial Distribution of Plankton Community in Tropical Reservoirs. In REDDY, MV. (Ed.). Restoration and Management of Tropical Eutrophic Lakes. Plymouth: Science Publishers. p. 271-300.

PINTO-COELHO, RM., PINEL-ALLOUL, B., MÉTHOT, G. and HAVENS K. E., 2005c. Crustacean zooplankton in lakes and reservoirs of temperate and tropical regions: variations with trophic status. Canadian Journal of Fisheries and Aquatic Scinces, vol. 62, p. 348-361.

REID, JW., 1989. The distribution of species of the genus Thermocyclops (Copepoda, Cyclopoida) in the western hemisphere, with a description of T. parvus, new species. Hydrobiologia, vol. 175, p. 149-174.

RIETZLER, AC. and ESPÍNDOLA, ELG., 1998. Microcystis as a food source for copepods in a subtropical eutrophic reservoir. Verhandlungen - Internationale Vereinigung für theoretische und angewandte Limnologie, vol. 26, p. 2001-2005.

RIETZLER, AC., ROCHA, O. and ESPINDOLA, ELG., 2004. Produção Secundária de Espécies do Zooplâncton do Reservatório de Salto Grande, Estado de São Paulo. In ESPINDOLA, ELG., LEITE, MA. and DORNFELD, CB. (Eds.). Reservatório de Salto Grande (Americana-SP): caracterização, impactos e propostas de manejo. São Carlos: Rima. p. 199-219.

ROCHA, O. and MATSUMURA-TUNDISI, T., 1984. Biomass and production of Argyrodiaptomus furcatus a tropical calanoid copepod in Broa reservoir, southern Brazil. Hydrobiologia, vol. 113, p. 307-311.

ROCHA, O., SENDACZ, S., MATSUMURA-TUNDISI, T., 1995. Composition, Biomass and Productivity of Zooplankton in Natural Lakes and Reservoirs of Brazil. In TUNDISI, JG., BICUDO, CEM. and MATSUMURATUNDISI, T. (Eds.). Limnology in Brazil. Rio de Janeiro: Brazilian Academy of Sciences, Brazilian Limnological Society. p. 151-166.

ROCHA, O., MATSUMURA-TUNDISI, T. and SAMPAIO, EV., 1997. Phytoplankton and zooplankton community structure and production as related to trophic state in some Brazilian lakes and reservoirs. Verhandlungen - Internationale Vereinigung für theoretische und angewandte Limnologie, vol. 26, p. 599-604.

ROSA, PG., 2008. Comunidade Zooplanctônica de Cinco Reservatórios Tropicais do Sistema Furnas S.A. (Brasil): Abundância e Biomassa de Carbono. Juiz de Fora: Universidade Federal de Juiz de Fora. 113 p. Dissertação de Mestrado em Ecologia.

SÁ JUNIOR, WP., 1994. Production of Planktonic Biomass for Feed of Alevins at the Furnas Hydrobiology and Hatchery Station. In Pinto-COELHO, RM., GIANI, A. and VON SPERLING, E. (Eds.). Ecology and Human impact on lakes and reservoirs in Minas Gerais with special reference to future development and management strategies. Belo Horizonte: SEGRAC. p. 133-139.

SAMPAIO, EV. and LÓPEZ, CM., 2003. Limnologias física, química e biológica da represa de Três Marias e do São Francisco. In GODINHO, HP. and GODINHO, AL. (Eds.). Águas, peixes e pescadores do São Francisco das Minas Gerais. Belo Horizonte: PUCMinas. p. 71-92.

SAMPAIO, IBM., 2002. Estatística Aplicada à Experimentação Animal. $2^{\mathrm{a}}$ ed. Belo Horizonte: Fundação de Ensino e Pesquisa em Medicina Veterinária e Zootecnia. 264 p.

SANTEIRO, RM., PINTO-COELHO, RM., 2000. Efeitos de fertilização na biomassa e qualidade nutricional do zooplâncton utilizado para alimentação de alevinos na esta- 
ção de Hidrobiologia de Piscicultura de Furnas, MG. Acta Scientiarum: Biological Sciences, vol. 22, p. 707-716.

SANTOS, MAPF., MELÃO, MGG. and LOMBARDI, AT., 2006. Life history characteristics and production of Ceriodaphnia silvestrii Daday (Crustacea, Cladocera) under different experimental conditions. Acta Limnologica Brasiliensia, vol. 18, p. 199-212.

SANTOS, RM., NEGREIROS, NF., SILVA, LC., ROCHA, O. and SANTOS-WISNIEWSKI, MJ., 2010. Biomass and production of Caldocera in Furnas Reservoir, Minas Gerais, Brazil. Brazilian Journal of Biology, vol. 70, p. 879887.

SANTOS-WISNIEWSKI, MJ., MATSUMURA-TUNDISI, T. and ROCHA, O., 2002. Spatial and Temporal Patterns of Zooplankton Biomass and Secondary Production in Barra Bonita Reservoir, Brazil. In Proceedings of fourth Inter- national Conference on Reservoir Limnology and Water Quality. Ceske Budejovice, TCH. p. 303-306.

SANTOS-WISNIEWSKI, MJ. and ROCHA, O., 2007. Spatial distribution and secondary production of Copepoda in a tropical reservoir: Barra Bonita, SP, Brazil. Brazilian Journal of Biology, vol. 67, p. 223-233.

SENDACZ, S., CALEFFI, S. and SANTOS-SOARES, J., 2006. Zooplankton Biomass of Reservoirs in Different Trophic Conditions in the State of São Paulo, Brazil. Brazilian Journal of Biology, vol. 66, p. 337-350.

TUNDISI, JG., MATSUMURA-TUNDISI, T., CALIJURI, MC., 1993. Limnology and management of reservoirs in Brazil. In STRAKRABA, M., TUNDISI, JG. and DUNCAN, A. (Eds.). Comparative Reservoir Limnology and Water Quality Management. Dordrecht: Kluwer Academic Publishers. p. 25-55.

WINBERG, GG. and DUNCAN, A., 1971. Methods for the estimation of production of aquatic animals. New York: Academic Press. 175 p. 